\title{
Mahua (Madhuca indica) (Koenig) J.F. Macribide) A Nature, Reward to Tribal Ecosystem of Central India
}

\author{
Yogesh Kumar ${ }^{1}$, Bharat Kumar ${ }^{2}$, Sandip Kumar Chandraker ${ }^{3}$, Gaurav Kumar Padwar ${ }^{1}$, \\ Ashish Kumar Dubey ${ }^{4}$, Tarun Kumar Thakur ${ }^{1}$ and M.L. Sahu ${ }^{5}$ \\ ${ }^{1}$ Department of Environmental Science, Indira Gandhi National Tribal University (IGNTU), \\ Amarkantak, Madhya Pradesh, India \\ ${ }^{2}$ Department of Horticulture, Jawaharlal Neharu Krishi Vishwa Vidyalaya, Jabalpur, India \\ ${ }^{3}$ Department of Botany, Indira Gandhi National Tribal University (IGNTU), \\ Amarkantak, Madhya Pradesh, India \\ ${ }^{4}$ Department of Horticulture, Sam Higginbottom Institute of Agriculture, Technology and \\ Science, Allahabad-211007 (U.P.), India \\ ${ }^{5}$ Department of Forestry, Jawaharlal Neharu KrishiVishwaVidyalaya, Jabalpur, India \\ *Corresponding author
}

\section{A B S T R A C T}

\section{Keywords}

Subsistence, Spiritual, Cultural, Medicinal and fermentation waste.

Article Info

Accepted:

15 March 2017

Available Online:

10 April 2017
The mahua tree is a nature reward to tribal's communities in India. The country has land of diverse group of tribes they still depend on the forest and its products for survival and subsistence of life. Among these forest products one of Madhuca indica which produce wide variety of products. The products obtained from tree are consumed by these communities itself or sale in local and regional market. Tree having great spiritual, cultural, medicinal, ornamental and multiple utility. It has been naturalized in different parts of Karnataka, Orissa, West Bengal, Rajasthan, Maharashtra, and Madhya Pradesh including various regions of India. There are many products namely; flower, seed, oil cake, leaf, timber etc. are obtained from mahua tree. The fermentation waste can also be used as bio fertilizer which is eco-friendly and cheap in comparison to the expensive fertilizers. Current study was undertaken to explore the socio-economic, cultural and livelihood of tribes in relation to wonder tree of $M$. indica and highlight and record in detail the uses of mahua tree growing in around AABR by tribal groups of central India.

\section{Introduction}

India is a land with diverse group of people. The country is a home for more than 400 tribal groups, who still depend upon traditional agriculture and forest for their livelihood and survival (Mishra et al., 2001). Tribal people fully depend upon nature and have developed a symbiotic relationship with surrounding ecosystem. Millions of people, particularly tribal and rural communities in many developing countries still collect and consumed a wide variety of wild plant resources to meet their food requirements (FAO, 2004; Balemie et al., 2006; Bharucha et al., 2010; Dobriyal et al., 2015). There are many tree species which play vital role in tribal livelihood, $M$. indica, 
is one of them. It is being preserved and sustainably utilized by tribes since ancient time. Current study was undertaken to explore the socio-economic, cultural and livelihood of tribes in relation to wonder tree of $M$. indica. It is commonly known as mahua or guli belongs to family sapotaceae. $M$. indica is the most important tree species in tribal point of view as it is used for varieties of purposes (Kala, 2011). It is having great spiritual, cultural, medicinal, and ornamental and multiple utility. Mahua seedlings in first two or three years grow slowly but in later years It treat as a fast growing tree attain height up to 20 meter and having evergreen to semi evergreen foliage according to site condition (Pankaj et al., 2008). It has been naturalized in different parts of Karnataka, Orissa, West Bengal, Rajasthan, Maharashtra, and Madhya Pradesh including various regions of India. It grows naturally in forest. It is one of those multipurpose forest tree species that provide an answer for the three major i.e. food, fodder and fuel (Patel et al., 2011). There are many products namely; flower, seed, oil cake, leaf, timber etc. are obtained from mahua tree. The fermentation waste can also be used as bio fertilizer which is eco-friendly and cheap in comparison to the expensive fertilizers (Jha et al., 2013). The every part of mahua tree is used in various manners by tribal and nontribal communities. This paper thus aims to highlight and record in detail the uses of mahua tree growing in around AABR by tribal groups of central India.

\section{Materials and Methods}

\section{Study area}

The AABR lays between $21^{\circ} 15^{\prime}$ to $22^{\circ} 58^{\prime} \mathrm{N}$ latitude and $81^{\circ} 25^{\prime}$ to $82^{\circ} 5^{\prime} \mathrm{E}$ longitude. The Achanakmar Amarkantak Biosphere Reserve is spread over an area of 383551.0 ha in Deccan Peninsula bio-geographic zone of Chhattisgarh and Madhya Pradesh and comprises of tropical moist deciduous to tropical dry deciduous forests. The total geographical area of AABR is 383551.0 ha of which 55155.0 ha is under the core zone and remaining 28396.889 ha comprises the buffer zone. The zonation in AABR makes clear the ecological and socio- economic independence between each zone of AABR. The core region of the AABR is situated in Chhattisgarh state whereas the buffer and transition zones lie partly both in Madhya Pradesh and Chhattisgarh. The AABR possessed rich plant and animal diversity. It is similarly known for its cultural diversity, as it is colonized by number of tribal and non-tribal group of people.

\section{Survey methods}

The present study was carried out in buffer zone and core zone's villages of AABR. A total of 7 villages in buffer zone namely Aamadoab, Kewanchi, Piper Khuti, Kachhratola, Roopand and Pattarconi, Madnadipo and 5 villages of core zone namely Lamni, Birarpani, Chhiritta, Atariyaa and Ranchaki were selected for intensive study on the multipurpose uses of mahua trees, which are shown in (Table 1). The selected villages of core zone were dominated by tribal communities while buffer zone has both tribal and non-tribal communities. The randomly selected tribe's hamlets and families from different communities were questionnaire survey in the selected villages of AABR. The major portions of questions were discussed with 60 to 70 years old people because they have great experience regarding the multiple uses of mahua products and its role in improvement of economy of concerned communities. Through questionnaire survey and interviews the information was collected on the indigenous uses of tree species, their processing techniques, and consumption pattern and plant part used by tribal and non-tribal 
communities of AABR which are shown in (Fig. 2). Beside of this information the questions were also asked on the role of mahua products on the economy of tribal community and non-tribal communities reside in and around the biosphere reserve. Besides questionnaire survey, the local people were encouraged to use the tree in sustainable manner. Efforts were made to scrutinize the tree species used in various socio-cultural practices of the local people including childbirth, death and marriage ceremony. The related cultural practices and norms for collection of plant part were also documented through group discussion. The experienced local people were also requested to escort during the forest survey for identification of tree species and related indigenous uses of mahua products.

Parts used by local people were cross-checked with other people and evaluate the result from personal interview and discussions in group with local people provide much valuable and specific information regarding the traditional uses of plant.

\section{Results and Discussion}

The present study brought it in to the light that there are many traditional use of Mahua tree which are well known by indigenous communities meanwhile the modern society have very minute or indefinite knowledge on these uses. The Average production of mahu stuff annually, depends on the site condition and climatic condition of the particular area. During the study we found that a mahua tree start yield on the age of 8-10 years and reached on the full bloom at the middle age, the average yield annually by a mahua tree at the age of 20-25 years shown in the table 3.

During the study result collected from various farms and house hold show that the mahua tree has vast potential to fulfill basic needs of these isolated communities. In view of sociocultural aspect of tribal society, mahua tree intermingled with various cultural, religious and social part of tribal life starting from birth to death. On child birth the leaf of mahua are tagged on the front door of house, the leaf of tree considered as witness of marriage in tribal community. Before fixing the marriage parents of girl take mahua leaf with them to boy's house. Drinks prepared from mahua flower are served during marriage ceremony. Trees also have vast potential with regard to economy of tribes.

The seed of mahua fetches 10 to 15 rupees in market, the flower consumed by society itself or sale in regional or local market at the rate of 40 to 50 rupees per $\mathrm{kg}$ shown in table 2 . The flowers are also used in preparation of jam, which is being made by tribal cooperative in Gadchiroli district of Maharashtra. The flower of mahua tree have used in different way by tribal and local communities of AABR which shown in figure 1.

The tender leaves are eaten by tribal communities itself. According to its economic and socio-cultural value in tribal community the tree considered as a natural reward of god. Due to multifunctional value of mahua tree, tribal community serves as conservation tool for it. However, conservation of this tree has been marginalized, as it is not favored by nontribal (Patil et al., 2004). Other than these uses, tree has vast pharmacological potential to treat several diseases.

Flowers are used to make syrup for medicinal purpose, seed oil used in rheumatism and to prevent cracks in the skin. Beside these uses the seed oil is the source of bio-fuel, leaves of tree are feed by the moth which produce tassar silk, a form of wild silk of commercial importance in India (FAO, 2013). 
Table.1 List of villages, surveyed in AABR

\begin{tabular}{|c|c|c|c|c|c|c|}
\hline \multicolumn{7}{|c|}{ Core zone } \\
\hline S.N & $\begin{array}{l}\text { Village } \\
\text { Name }\end{array}$ & GPS Location & $\begin{array}{c}\text { Elevation } \\
\text { MSL(m) }\end{array}$ & Informants & Localities & $\begin{array}{c}\text { Population } \\
\text { (2011 census) }\end{array}$ \\
\hline 1. & Lamni & $\begin{array}{l}\text { N-22 } 22^{0} 32^{\prime} 32.53^{\prime \prime} \\
\text { E-81 } 81^{\prime} 37.20^{\prime \prime}\end{array}$ & 569 & 18 & 4 & 634 \\
\hline 2. & Birarpani & $\begin{array}{l}\mathrm{N}-22^{0} 32^{\prime} 36.30^{\prime}, \\
\mathrm{E}-81^{0} 38^{\prime} 36.70^{\prime \prime}\end{array}$ & 781 & 13 & 3 & 75 \\
\hline 3. & Chhirhatta & $\begin{array}{l}\mathrm{N}-22^{0} 31^{\prime} 23.50^{\prime \prime} \\
\mathrm{E}-81^{0} 41^{\prime} 46.60^{\prime \prime}\end{array}$ & 446 & 11 & 3 & 94 \\
\hline 4. & Atariya & $\begin{array}{l}\text { N-22 } 34^{0} 08.07^{\prime \prime} \\
\text { E-81 } 41^{0} 12.71^{\prime \prime}\end{array}$ & 598 & 17 & 5 & 668 \\
\hline 5. & Ranchaki & $\begin{array}{l}\mathrm{N}-22^{0} 34^{\prime} .445^{\prime} \\
\mathrm{E}-81^{0} 41^{\prime} .553^{\prime}\end{array}$ & 701 & 15 & 3 & 342 \\
\hline \multicolumn{7}{|c|}{ Buffer Zone } \\
\hline S.N & Village Name & GPS Location & $\begin{array}{c}\text { Elevation } \\
\text { MSL(m) }\end{array}$ & Informants & Localities & $\begin{array}{c}\text { Population } \\
\text { (2011 census) }\end{array}$ \\
\hline 1. & Aamadob & $\begin{array}{l}\text { N-22 } 32^{0} 37^{\prime} 17.68^{\prime \prime} \\
\text { E-81 } 41^{0} 44^{\prime} 10.77^{\prime \prime}\end{array}$ & 656 & 21 & 4 & 1208 \\
\hline 2. & Kewanchhi & $\begin{array}{l}\mathrm{N}-22^{0} 37^{\prime} 17.73^{\prime \prime} \\
\text { E-81 } 41^{0} 46^{\prime} 44.82^{\prime \prime}\end{array}$ & 578 & 23 & 6 & 846 \\
\hline 3. & PiparKhuti & $\begin{array}{l}\text { N-22 } 32^{0} 39^{\prime} 36.33^{\prime \prime} \\
\text { E-81 } 52^{\prime} 08.80^{\prime \prime}\end{array}$ & 596 & 27 & 8 & 786 \\
\hline 4. & Kachhratola & $\begin{array}{l}\mathrm{N}-22^{0} 40^{\prime} 47.45^{\prime \prime} \\
\text { E-81 } 52^{\prime} 59.82^{\prime \prime}\end{array}$ & 600 & 11 & 2 & 332 \\
\hline 5. & Roopandand & $\begin{array}{l}\text { N-22 } 42^{\circ} 52.17^{\prime} \\
\text { E-81 }\end{array}$ & 591 & 13 & 3 & 1003 \\
\hline 6. & Paterkoni & $\begin{array}{l}\mathrm{N}-22^{0} 42^{\prime} 55.83^{\prime \prime} \\
\text { E-81 } 51^{0} 53^{\prime} 48.02^{\prime \prime}\end{array}$ & 594 & 09 & 2 & 787 \\
\hline 7. & Madana & $\begin{array}{l}\mathrm{N}-22^{0} 43^{\prime} 42.82^{\prime \prime} \\
\mathrm{E}-81^{0} 54^{\prime} 07.54^{\prime \prime}\end{array}$ & 604 & 23 & 5 & 861 \\
\hline
\end{tabular}


Table.2 Different products of mahua sold by tribes in local/region market

\begin{tabular}{|c|c|c|}
\hline S.No. & Products of $M$. indica & local/region market price \\
\hline 1 & Flower & $40-50$ Rupees $/ \mathrm{kg}$ \\
\hline 2 & Seed & $10-15$ Rupees $/ \mathrm{kg}$ \\
\hline 3 & Oil & $10-12$ Rupees $/ \mathrm{kg}$ \\
\hline 4 & Oil cake & $3-5$ Rupees $/ \mathrm{kg}$ \\
\hline 5 & Fermentation west treat as a fertilizer & $2-3$ Rupees $/ \mathrm{kg}$ \\
\hline 6 & Fuel wood & $20-30$ Rupees $/ \mathrm{kg}$ \\
\hline 7 & Timber & $800-1000$ Rupees $/ \mathrm{cubic} \mathrm{ft}$ \\
\hline 8 & Liquor & $90-100$ Rupees $/ \mathrm{kg}$ \\
\hline
\end{tabular}

Table.3 Standard twelve-monthly give up of mahua stuff

\begin{tabular}{|c|c|c|c|}
\hline S.N & Products & Avg. annual yield/Tree kg. & Remark \\
\hline 1. & Seed & $40-50$ & According to age of tree\& site condition \\
\hline 2. & Flower & $200-250$ & According to age of tree \& site condition \\
\hline 3. & Kernel & $25-35$ & According to age of tree \& site condition \\
\hline 4. & Leaf & $200-250$ & According to age of tree \& site condition \\
\hline 5. & Oil from kernel & Ghana & $25-30 \%$ of the kernel \\
& & Expellers & $30-37 \%$ of the kernel \\
& & Solvent Extraction Plants & $40-45 \%$ of the kernel \\
\hline
\end{tabular}

Fig.1 Uses of mahua flowers in different types of food products (Sinha et al., 2017)

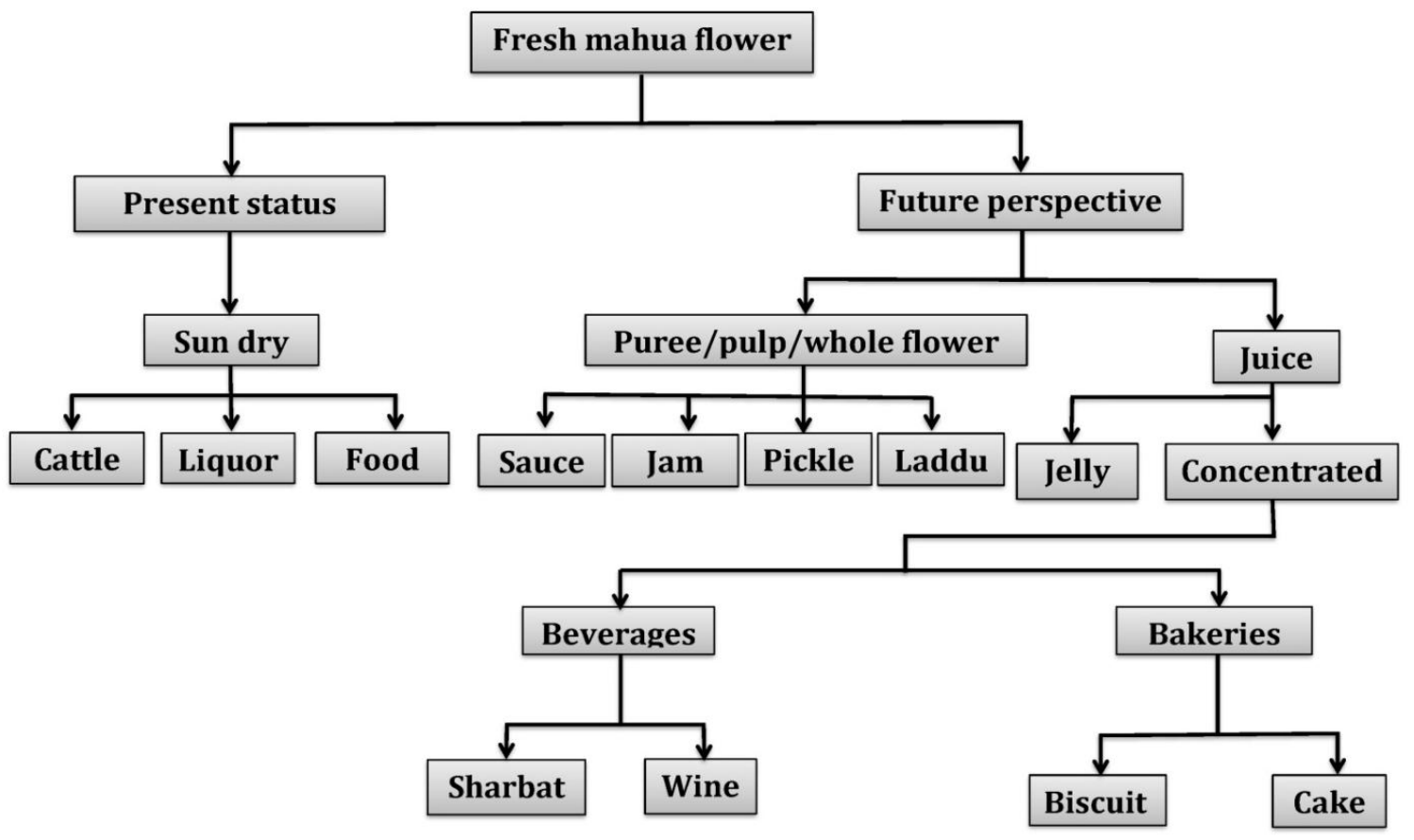


Fig.2 (A) Tree of $M$. indica, (B) Flower of $M$. indica, (C) Lot flowers of $M$. indicafor marketing and (D) Marketing of flower of $M$. indicaby tribal
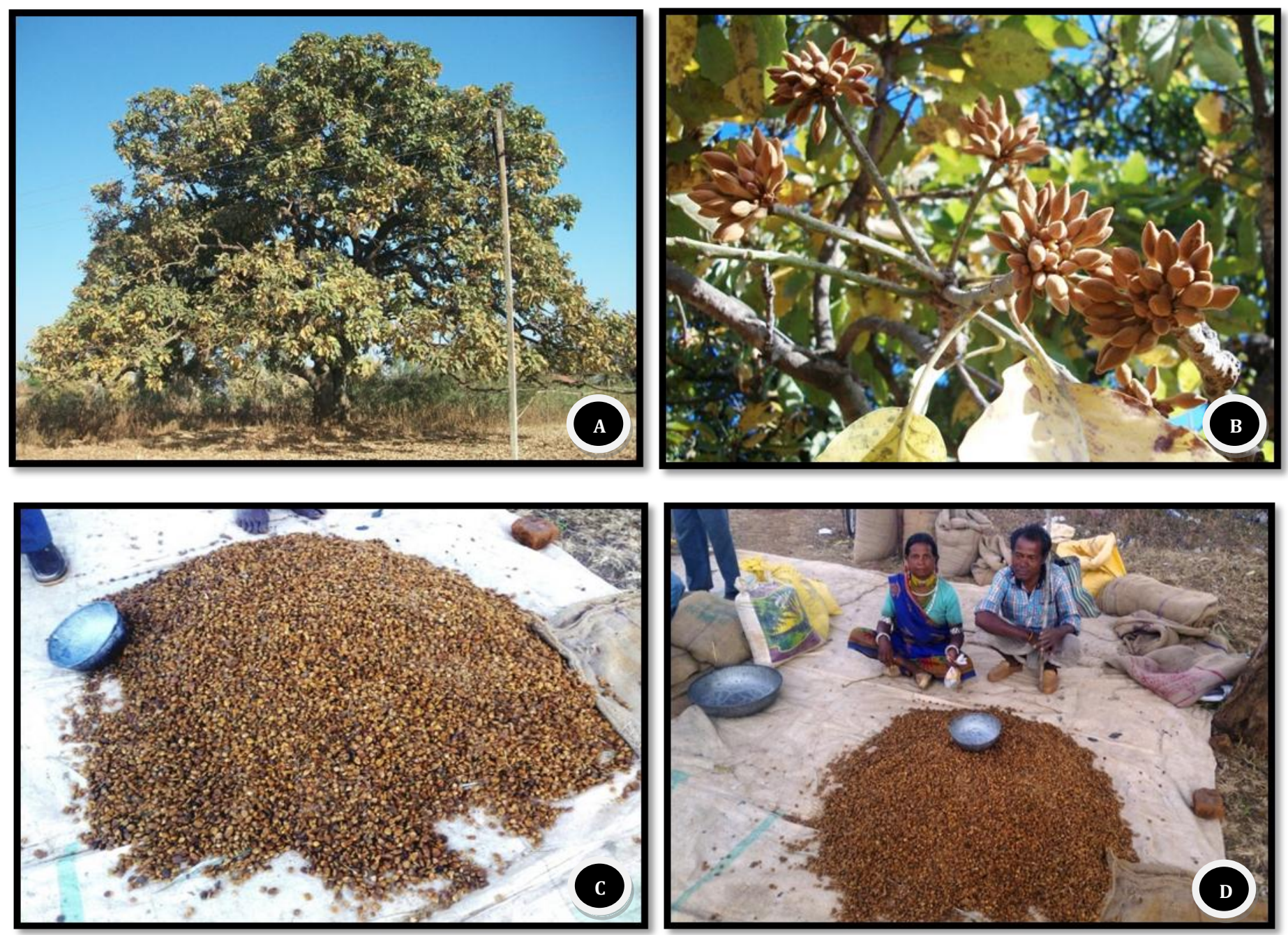

The mahua tree products collected form forest or nearby village are sale in local or regional market by the local people of AABR. These products play important role in the viability and survival of tribal and non-tribal communities of AABR. Forest dwellers of AABR collected these products from forest or nearby village area for household consumption and also for sale in the market. Many of these products are found to be sold in the local markets particularly by poor and economically marginalized families, thereby generating a supplementary income to their household economy (Panda, 2014). Many earlier workers, worldwide also reported that forest is a source of subsistence of these isolated communities (Chittaranjan, 2005; Colchester et al., 2006; Muhaammed et al., 2010; Khera, 2016). The forest products are very economically important in point of view of subsistence of local people of BR. In case of these indigenous communities, the major factor of economics such as production, consumption and distribution are closely associated with forest (Chittaranjan, 2005). These hidden societies of the word have great 
assumption that the natural resources have only means of survival of our lives. Utilization of forest resources is a prerequisite for the livelihood of remote villagers who do not have many other alternative source of income (Yeo-Chang, 2009). It is concluded that the $M$. indica tree has vast potential to fulfill the needs of these isolated societies. So the need come forward to documentation and conserve this tree and for future society.

In conclusion the results of this study has revealed that indigenous traditional knowledge on the use of mahua tree for various purpose like edible food, vegetables and cure to certain diseases is still practiced by the local communities of AABR. Beside, these uses the particular tree is also source of income, they sale some products in local or regional market. The local communities very well know about the exact uses of mahua tree, which are little known or unknown to modern societies. So there is a strong need of documentation and conservation of these particular species for as a source of food, medicine, and sources of income at a time of scarcity.

\section{Acknowledgement}

I express gratitude to Kunni Bai, Aghni Bai, Shamli Bai are female of Baiga tribe and Manglu Baiga, Bhudhsi Gond, satishkoal, Tukarampradhan and vishen Singh Baiga whose fruitful support made us to collect valuable information about the indigenous uses of mahua tree and its role in tribal's economy.

\section{References}

Balemie, K. and Kebebew, F. 2006. Ethnobotanical study of wild edible plants in Derashe and Kucha Districts, South Ethiopia. J. Ethnobiol. Ethnomed., 2: 53-61.
Bharucha, Z. and Pretty, J. 2010. The roles and values of wild foods in agricultural systems. Phil. Trans. Royal Soc. B., 365: 2913-2926.

Chittaranjank, P. 2005. A text book 'Forest government and tribe".

Colchester, M. 2006. Justice in the forest: Rural lively hoods and forest law enfo: forest perspectives, CIFOR, Indonesia.

Dobriyal, Manmohan, J.R. and Dobriyal, R. 2015. Non wood forest produce: an option for ethnic food and nutritional security in India. Int. J. Usuf. Mngt., 15(1): 17-37

Food and Agriculture Organization of the United Nations (FAO). 2004. Annual Report: The state of food insecurity in the world, monitoring the progress towards the world food summit and millennium development goals, Rome.

Forest Department. 2012-12-04. LIT develop new products from mahua - The Times of India, the Times of India.

Jha, S., Vaibhav, V. and Suneetha V. 2013. A Culinary Mahua (Madhucaindica) flower from Bihar, India A potential in production of jam, alcohol for pharmacological benefits with fertilizer value. Int. J. Drug Dev. Res., 5(2): 362367.

Kala, C.P. 2011. Indigenous uses and sustainable harvesting of trees by local people in the Pachmarhi Biosphere Reserve of India. Int. J. Med. Arom. Plants, Vol. 1, No. 2, pp. 153-161.

Khera, A. 2016. Poverty alleviation through non wood forest products in Madhya Pradesh. J. Trop. Forestry, 32 (ii), 7-10.

Mishra, K.K., Murty, M.L.K. 2001. A text book on "peoples and environment in India".

Muhaammed, N.V.D. and Sheeladitya, R.C. 2010. Livelihood pattern and forest dependence of the major tribes in Rangamati Bangladesh, Shinshu, 
University International symposium 20 02-2010.

Non-Wood Forest Products in 15 Countries of Tropical Asia: An Overview. Fao.org. Retrieved 2013-11-21.

Oudhia, P., and Robert, E., Paull. 2008. Butter tree Madhucalatifolia Roxb. Sapotaceae 827-828. Encyclopedia of AFruit and Nuts, J. Janick and R. E. Paull -editors, CABI, Wallingford, United Kingdom.

Panda, T. 2014. Traditional knowledge on wild edible plants as livelihood food in Odisha, India. J. Biol. Earth Sci., 4(2): 144-159.

Patel, M., Pradhan, R.C. and Naik, S.N. 2011. Physical properties of fresh mahua. Int. Agrophys., 25: 303-306.
Patil, D.A., Pawar, S. and Patil, M.V. 2004. Mahuwa tree and the aborigines of North Maharashtra, Natural Product Radiance, 3(5): 360-361.

Product Profile, Mahuwa, Trifed, Ministry of Tribal Affairs, Government of India. Trifed.nic.in. Retrieved 2013-11-21.

Sinha, J., Singh, V., Singh, J., and Rai, A.K. 2017. Phytochemistry, Ethnomedical Uses and Future Prospects of Mahua (Madhucalongifolia) as a Food: A Review. J. Nutr. Food Sci., 7: 573.

Yeo-Chang, Y. 2009. Use of forest resources, traditional forest-related knowledge and livelihood of forest dependent communities: Case in South Korea. Forest Ecol. Manage., 257: 2027- 2034.

\section{How to cite this article:}

Yogesh Kumar, Bharat Kumar, Sandip Kumar Chandraker, Gaurav Kumar Padwar, Ashish Kumar Dubey, Tarun Kumar Thakur and M.L. Sahu. 2017. Mahua (Madhuca indica) (Koenig) J.F. Macribide) A Nature, Reward to Tribal Ecosystem of Central India. Int.J.Curr.Microbiol.App.Sci. 6(4): 1519-1526. doi: https://doi.org/10.20546/ijcmas.2017.604.186 